\title{
Measuring Mental Model of Primary Teachers and Pre-service Teachers on Heat Transfer Concept
}

\author{
Neni Hermita ', Zetra Hainul Putra 2, Novi Yani Yora 3, Tommy Tanu Wijaya \\ 4, Andi Suhandi 5 \\ DOI: $10.35445 /$ alishlah.v13i1.351
}

\section{Info Artikel}

Keywords: Mental model

Heat transfer concept

\begin{abstract}
This study compares primary teachers' mental models with pre-service primary school teachers' mental models on the heat transfer concept. The mental model categories reviewed in this study include scientific, synthetic, and initial. This study's method was descriptive quantitative method, with research subjects 40 primary teachers and 40 pre-service primary teachers. This study's instrument is a conceptual understanding test consisting of three parts of a statement that asks for an explanation and description. The results showed that in understanding concepts test in synthetic mental models, $32.5 \%$. In the category of initial mental models, there is a comparison of $32.5 \%$. While in the concept of convection, there is a comparison of $2.5 \%$ in the scientific category. For synthetic mental models' category is $5 \%$. In the category of initial mental models is $7.5 \%$. For the concept of radiation, there is no comparison in the category of scientific mental models. Next there is a comparison of $7.5 \%$ in the category of synthetic mental models. In the category of initial mental models is $7.5 \%$. Generally, elementary school teachers and students are in synthetic mental models and the initial mental models' category.
\end{abstract}

Kata kunci: Model Mental Konsep perpindahan panas

\begin{abstract}
Abstrak
Tujuan dari penelitian ini adalah untuk mendeskripsikan perbandingan model mental guru sekolah dasar dengan model mental calon guru sekolah dasar pada konsep perpindahan panas. Kategori model mental yang ditinjau dalam penelitian ini meliputi scientific, synthetic dan initial. Metode dalam penelitian ini adalah metode deskriptif kuantitatif, dengan subjek penelitian 40 guru sekolah dasar dan 40 calon guru sekolah dasar. Instrumen penelitian ini berupa tes pemahaman konseptual yang terdiri dari tiga bagian pernyataan yang meminta penjelasan dan deskripsi. Hasil penelitian menunjukkan bahwa tes pemahaman konsep pada model mental synthetic $32,5 \%$. Pada kategori model mental initial terdapat perbandingan sebesar $32,5 \%$. Sedangkan pada konsep konveksi pada kategori scientific terdapat perbandingan sebesar 2,5\%. Untuk kategori model mental synthetic adalah 5\%. Pada kategori model mental initial adalah $7,5 \%$. Untuk konsep radiasi, tidak ada pembanding dalam kategori model mental scientific. Selanjutnya ada perbandingan $7,5 \%$ pada kategori model mental synthetic. Pada kategori model mental initial
\end{abstract}

\footnotetext{
${ }^{1}$ Universitas Riau, Pekanbaru, Indonesia

Email: neni.hermita@lecturer.unri.ac.id

2 Universitas Riau, Pekanbaru, Indonesia

3 Universitas Riau, Pekanbaru, Indonesia

4 Guangxi Normal University, China

5 Universitas Pendidikan Indonesia, Bandung, Indonesia
} 
adalah 7,5\%. Secara umum guru dan calon guru sekolah dasar termasuk dalam kategori model mental synthetic dan kategori model mental initial.

\section{INTRODUCTION}

Problems related to the duty of an educator become a discussion in the community so that the aspect of competence that educators must own becomes the public assessment (Cunhua, Ying, Qunzhuang, \& Wijaya, 2019; Hutajulu, Wijaya, \& Hidayat, 2019). The low quality of learning caused by demands for an educator and the low competency possessed by educators also causes the process of learning not to run optimally (Kulsum, Hidayat, Wijaya, \& Kumala, 2019; Qin, Zhou, \& Tanu, 2019; Tommy Tanu Wijaya, Ying, Chotimah, \& Bernard, 2020). In other aspects, educators are required to be able to provide the best for their students (T.T. Wijaya, Ying, \& Purnama, 2020a). Good teaching and learning activity can achieve the learning objectives themselves (T.T. Wijaya, Ying, \& Ya, 2020). A quality learning process is needed to achieve a good learning course (T.T. Wijaya, Ying, \& Suan, 2020).

Educators who also play an essential role in learning and essential competency that teachers must possess are mastery of learning material (T.T. Wijaya, Jianlan, \& Aditya, 2020; T.T. Wijaya, Ying, \& Purnama, 2020b). One of the essential goals of learning a field of science is that students can master the scientific field as a whole. This goal will be achieved if the teacher in charge of science. To achieve the expected learning, the teacher, as the organizer of learning, also understands the teaching material that will be taught to students (Badraeni et al., 2020; T.T. Wijaya, Dewi, Fauziah, \& Afrilianto, 2018). Teacher professional competence can be prepared early through pre-service when they attend prospective teachers' education in an educational organization that includes a university.

(Westbrook, 2006) Explains that there is five core formation of learning organizations in school or university. These five things are; 1) System Thinking, 2) Personal Mastery, 3) Mental Model, 4) Building Vision, and 5) Team Learning (Westbrook, 2006). Mental models become one of the essential things to know or explore in improving the quality of learning. The increase in the quality of learning also affects the quality of education.

Mental models are reasoning mechanisms that exist in one's working memory (Jones, Ross, Lynam, Perez, \& Leitch, 2011). As for other opinions namely, Jia (2010) states that the mental model in the learning activity is the student's process in constructing cognitive structures referring to old knowledge and new knowledge. Mental models can connect or initiate information and use it to produce explanations (D. Besnard, 2018). According to Laliyo (2011), mental models are exciting because mental models affect cognitive functions and provide valuable information for science education researchers about students' concepts. The mental model can be identified by interpreting expressed mental models, namely mental models expressed using oral, written, and pictured (Coll \& Treagust, 2003). Mental models developed by students are of two kinds, namely scientific mental models and non-scientific mental models. Halim, Ali, Yahaya, and Said (2013) state that nonscientific mental models are incompatible with scientific concepts (Amalia, Ibnu, Widarti, \& Wuni, 2018; Hermita et al., 2020). The mental model is a description of students' thoughts about a situation that is delivered with an explanation and reasons related to a particular case.

So that prospective teachers do not experience misunderstandings, the most important thing that a teacher must have is a comprehensive understanding of the concept. This is reflected in the mental model possessed by prospective teachers. The picture that is formed in the mind of a prospective teacher can be seen how to explain and convey an understanding of the concepts they have (Johnson-Laird, 2013) to support one's understanding and logical thinking in a condition that is formed spontaneously (Dedre Gentner \& Stevens, 2014). Mental models can also differentiate students to understand a concept of experiencing an error or not (Chiou, 2013; Didiş, Erylmaz, \& Erkoç, 2014; Khasanah, Wartono, \& Yuliati, 2016; Kurnaz \& Eksi, 2015). 
Mental models inform how a person can understand, learn, remember and think about information. The mental model is the structures of knowledge that individuals construct to understand and explain their concept experiences. Therefore, mental models that are personal representations and are expressed from one's experience need to be examined to improve learning. In his theory (Goldin, 2002), language in conveying something to others is the main thing of representation. Representation also means interpreting or expressing concepts in mind by using language or words. In the classroom, the pre-service teacher's situation is certainly not like a blank paper. However, it already has an initial conception obtained through interaction with the environment and will differ from other individual concepts (Hermita, 2017). Every concept has a scientifically clear description and has been agreed by scientists and student and teacher representations. The scientific mental model reflects a sound or comprehensive understanding (Parlina, Hermita, Alpusari, \& Noviana, 2019). The mental model provides a powerful mechanism for storing knowledge in the human mind. Because of how these structures can affect human behaviour, they have a significant impact on almost all forms of human activity Fazio (in Parlina et al., 2019). Children's understanding based on daily life experiences is the keyword so that learning at school can be easily reflected by referring to their actual experiences. However, in science learning, students often find this learning difficult and complicated. This is because learning science in students' eyes means learning something abstract (Hermita et al., 2020).

Mental models are owned by every individual, both students and teachers, can be seen in several studies, such as research conducted by Suhandi, Rusdiana, Samsudin, and Wibowo (2019). That study aims to describe pre-service physics teachers' level of mental models on electricity concept. In analyzing problems, pre-service physics teachers answer questions based on intuition and daily experience without using appropriate concepts. Pre-service physics teachers were not able to analyze, access, build on the elements of knowledge acquired during college, and their answers are not represented coherently. Other research conducted by Supriadi, Ibnu, and Yahmin, (2018) aims to explore students' mental models in understanding various types of chemical reactions based on differences in initial knowledge. The study results indicate that almost all students are still developing mental models at the initial level in responding to the phenomenon of reaction at the submicroscopic level, and there are no students who have developed a scientific mental model. The lack of a students' mental model level is caused because, in the learning process, students are rarely given learning that can improve students' scientific abilities Supriadi et al. (2018). Based on previous research, it can be seen that the mental models of each individual are different. Therefore, this study aims to compare primary teachers' mental models and pre-service primary teachers' mental models. Some students' process an initial conception, but some others do not have it. Students who already have the initial conception can have the scientific conception or not, or it is frequently mentioned that they have a misconception or alternative conception (Basori, Suhandi, Samsudin, Kaniawati, \& Rusdiana, 2020). Misconceptions about physical science concepts are not limited to children; they are also maintained throughout high school and into college, alerting researchers of the need to identify and challenge pre-service teachers' understandings of physical science before entering the classroom (Parlina et al., 2019).

\section{METHOD}

The methods utilize comparative methods to compare similarities and differences in research subjects (Notoatmodjo, 2010) and quantitative descriptive methods. The subjects of this study were 40 primary teachers and 40 pre-service primary teachers at Universitas Riau. The instrument used to collect data in this study was a level understanding of heat transfer concepts. Every test item consists of three question sections, two questions verbal explanation responses and description responses in the representation of microscopic images. Conceptual understanding tests are used to identify the state of conceptual understanding of primary teachers and pre-service primary teachers. 
There are three items of conceptual understanding test items, each related to the concepts of conduction, convection, and radiation. Instrument test items are shown in Table 1.

\section{Table 1. Instrument Level of Understanding Test on Heat Transfer Concept No Concept $\quad$ Indicators Question}

1 Conduction a. Explaining the definition of conduction.

b. Explain the physical mechanism of the conduction process.

c. States in the representation of microscopic picture the physical mechanism of the conduction process a. What is conduction heat transfer? Explain it!

b. Explain how the heating mechanism can move by conduction!

c. Describe the process of heat transfer conditional microscopically!

\begin{tabular}{|c|c|c|c|}
\hline 2 & Convection & $\begin{array}{l}\text { a. Explaining the definition of } \\
\text { convection. } \\
\text { b. Explaining the physical } \\
\text { mechanism of the convection } \\
\text { process. } \\
\text { c. States in the representation of } \\
\text { microscopic picture the } \\
\text { physical mechanism of the } \\
\text { convection process. }\end{array}$ & $\begin{array}{l}\text { a. What is convection heat } \\
\text { transfer? Explain it! } \\
\text { b. Explain how the heating } \\
\text { mechanism can move by } \\
\text { convection! } \\
\text { c. Describe the process of } \\
\text { heat transfer by } \\
\text { convection } \\
\text { microscopically! }\end{array}$ \\
\hline 3 & Radiation & $\begin{array}{l}\text { a. Explaining the definition of } \\
\text { radiation. } \\
\text { b. Explaining the physical } \\
\text { mechanism of the radiation } \\
\text { process, } \\
\text { c. States in the representation of } \\
\text { microscopic images the } \\
\text { physical mechanism of the } \\
\text { radiation process }\end{array}$ & $\begin{array}{l}\text { a. What is radiation heat } \\
\text { transfer? Explain it! } \\
\text { b. Explain how the heating } \\
\text { mechanism can move by } \\
\text { radiation! } \\
\text { c. Describe the process of } \\
\text { heat transfer by radiation } \\
\text { microscopically! }\end{array}$ \\
\hline
\end{tabular}

Table 2. The Rubric for Determining Mental Models on Heat Transfer Concept (Kurnaz \& Eksi, 2015)

\begin{tabular}{lll}
\hline $\begin{array}{c}\text { Model } \\
\text { mental } \\
\text { (MM) }\end{array}$ & \multicolumn{1}{c}{ Content } & \multicolumn{1}{c}{ Criteria } \\
\hline Scientific & $\begin{array}{l}\text { The perception of the subject } \\
\text { according to scientifically } \\
\text { acceptable }\end{array}$ & $\begin{array}{l}\text { Scores for questions A, B and C } \\
\text { are all high (3 or 4); there are no } \\
\text { scores below 3 }\end{array}$ \\
\hline Synthetic & $\begin{array}{l}\text { The perception of the subject is } \\
\text { partly appropriate and partly } \\
\text { unacceptable scientifically }\end{array}$ & $\begin{array}{l}\text { Scores for questions A, B and C } \\
\text { (partly high (3 or 4) but partly } \\
\text { low (o or 1 or 2) }\end{array}$ \\
\hline Initial & $\begin{array}{l}\text { Subject perception cannot be } \\
\text { scientifically accepted }\end{array}$ & $\begin{array}{l}\text { Scores for questions A, B and C } \\
\text { are all low or below 3 (can be o or } \\
\text { 1 or 2) }\end{array}$ \\
\hline \hline
\end{tabular}

Subject data in this study were taken using the questions in Table 1, and then the subject's answers were categorized at the level of mental models following Table 2. After the mental model level of primary teachers and pre-service primary teachers is categorised, the data were then processed to find the number of percent at each mental models of primary teachers and pre-service 
primary teachers. Furthermore, elementary school teachers' mental model data on each item were compared with the mental model data obtained by primary teachers and pre-service primary teachers.

\section{FINDINGS AND DISCUSSION}

Data has collected through the conceptual understanding level test from 40 primary teachers and 40 pre-service primary teachers. Supporting conceptual understanding of elementary school teachers based on the concept of heat transfer was presented in three broad headings, namely: Primary Teachers' Mental Models Categories, Pre-Service Primary Teachers' Mental Models Categories and Comparison of Primary Teachers and Pre-service Primary School Teachers' Mental Models.

\section{Subsections as part of its main section}

Based on the results of the conceptual understanding level test of 40 primary teachers, the data obtained categories of primary teachers' mental models related to the heat transfer concept. Data on the categories of primary teachers' mental models on heat transfer concept were presented in Table 3 .

\section{Table 3. Categories of Primary Teachers' Mental Models Based on the Level of Conceptual Understanding on Heat Transfer Concept}

Concepts

\begin{tabular}{lcccccc}
$\begin{array}{c}\text { Model Mental } \\
\text { Categories }\end{array}$ & $\begin{array}{c}1 \\
\text { (Conduction) }\end{array}$ & $\begin{array}{c}2 \\
\text { (Convection) }\end{array}$ & $\begin{array}{c}3 \\
\text { (Radiation) }\end{array}$ \\
\hline Scientific & 0 & $0 \%$ & 1 & $2.5 \%$ & 0 & $0 \%$ \\
Synthetic & 22 & $55 \%$ & 15 & $37.5 \%$ & 23 & $57.5 \%$ \\
Initial & 18 & $45 \%$ & 24 & $60 \%$ & 17 & $42.5 \%$ \\
Total & 40 & $100 \%$ & 40 & $100 \%$ & 40 & $100 \%$ \\
\hline \hline
\end{tabular}

From Table 3, it can be seen on conduction concept, there were no primary teachers who are able to reach the scientific mental model. As many as $55 \%$ of primary teachers were in the category of synthetic mental models. Furthermore, for the convection concept, only $2.5 \%$ of primary teachers are in the scientific category. This means that from 40 primary teachers, only one elementary school teacher was able to explain the convection concept scientifically. More than half of the teachers are in the category of initial mental models on the convection concept. It means they are only able to explain the convection concept based on their initial understanding. For the radiation concept, there were no primary teachers who have a category of scientific mental models. They have not been able to explain the radiation concept scientifically. In this concept, generally, primary teachers were in synthetic mental models categories.

Below is an example of an elementary school teacher's answer that belongs to the scientific category. 


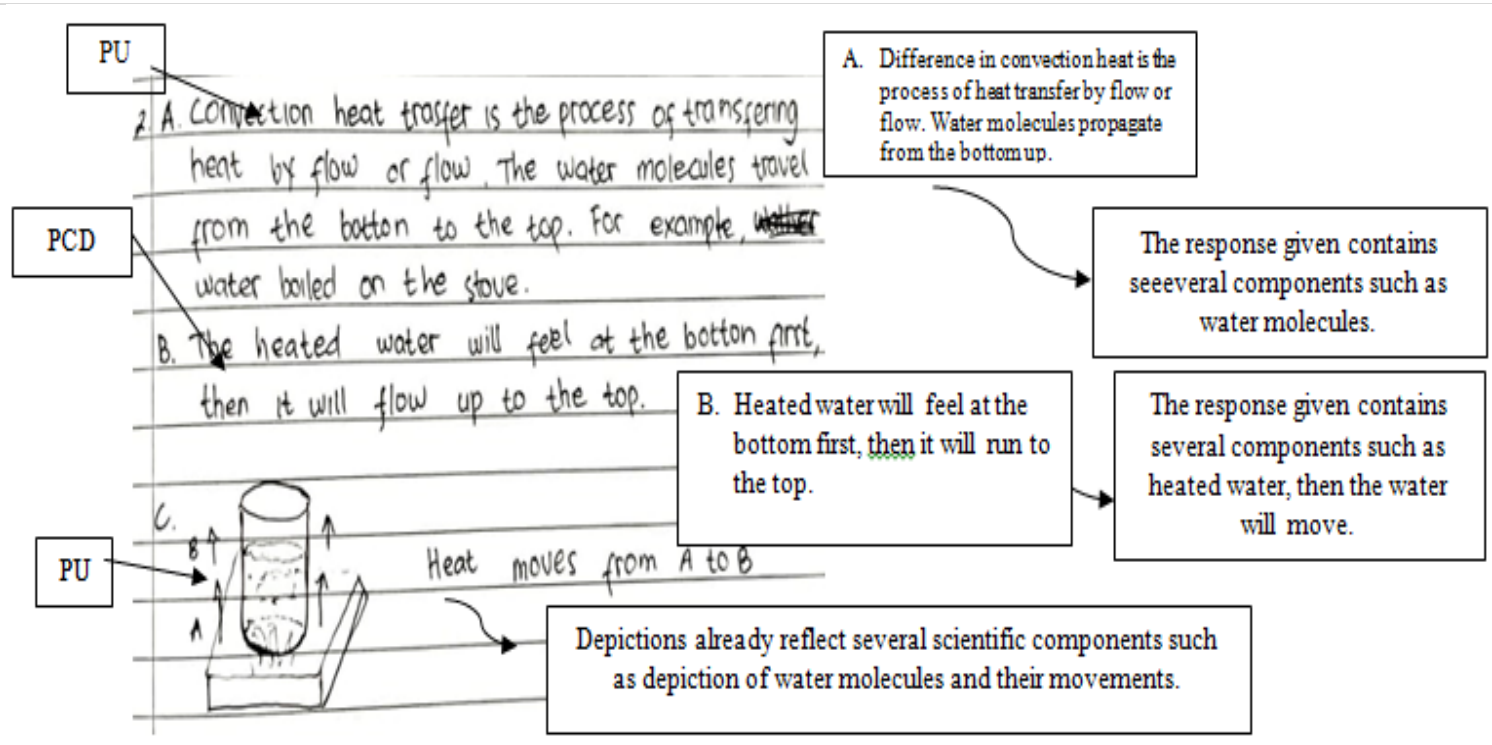

\section{Figure. 1. Primary Teachers' Response in the Scientific Category}

Figure 1 is primary teachers response in the scientific category, the answer 2 points A, B get the PU understanding level because the teacher's response has been able to explain several components regarding the definition of heat transfer by convection and the process of heat transfer by convection with the response can be accepted scientifically. For image, C gets a level of PCD understanding because the image created already reflects some of the components of a scientific description.

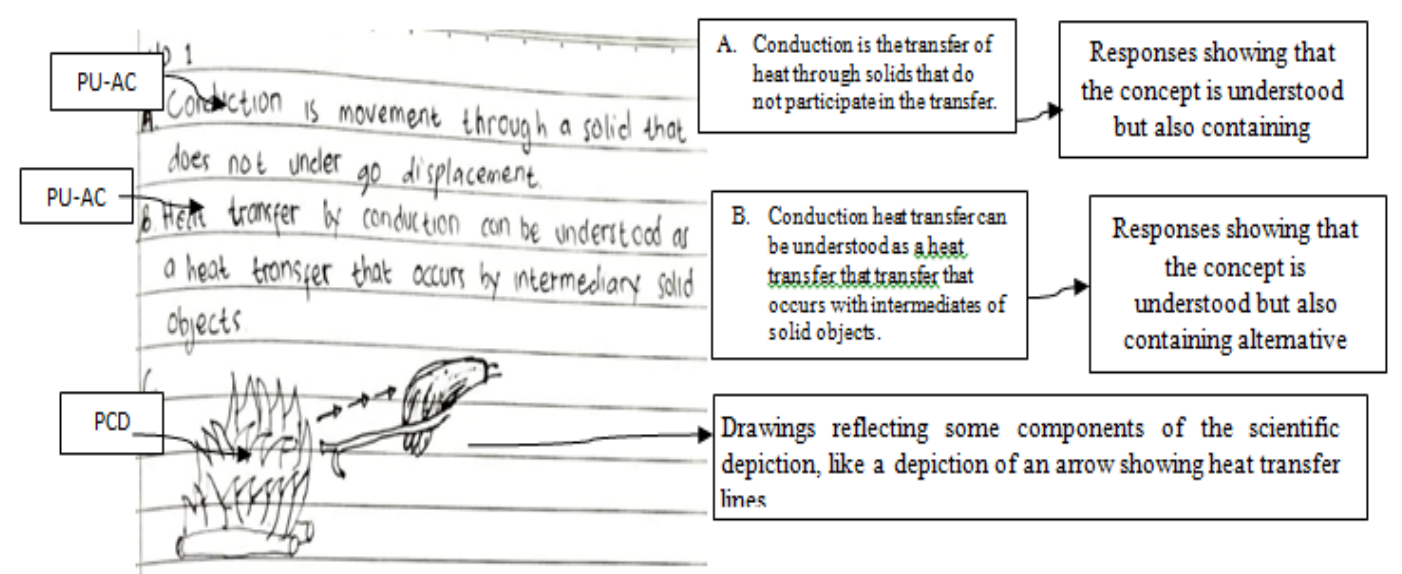

Figure. 2. Primary Teachers' Response in the Synthetic Category

Figure 2 shows the responses of primary teachers that fall into the category of Scientific mental models where answer A is at the level of PU-AC understanding and answer B includes the level of PU-AC understanding, for responses A and B are included in the level of PU-AC understanding because the responses given by school teachers the basis shows the concept of heat transfer by conduction both the definition and the process can be understood but also contains other conceptions and answers C for the PCD level understanding because the picture already reflects several description scientific components. 


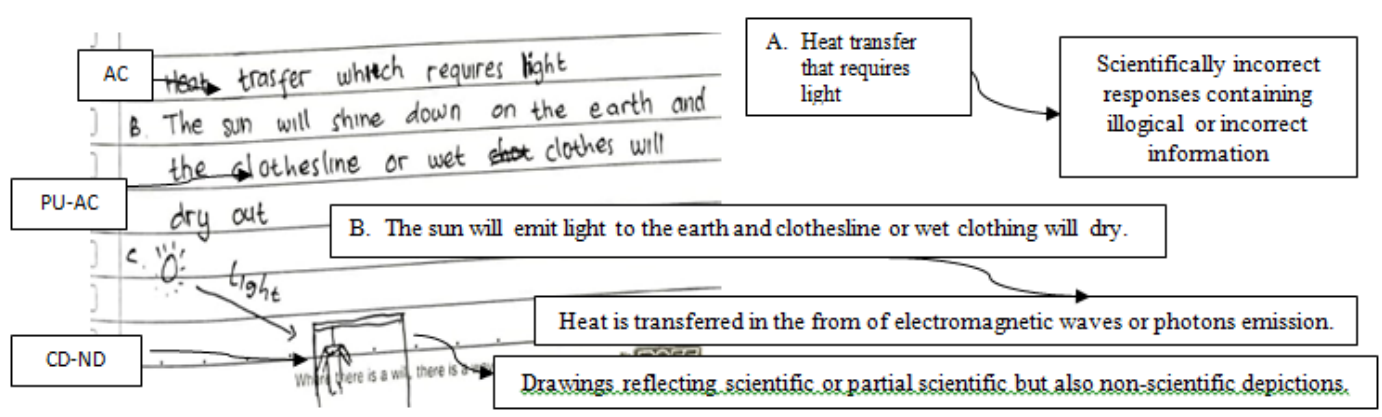

Figure. 3. Primary teachers' response in the Initial Category

Figure 3 shows primary teachers response in the initial category. For answer A, it includes the level of $\mathrm{AC}$ understanding because the answer given does not match the desired concept, for answer B includes the PU-AC understanding level. For the answer, C includes the CD-ND understanding level because the picture is wrong.

\section{Pre-Service Primary Teachers' Mental Models Categories} in Table 4.

Pre-service primary teachers' mental models' categories on heat transfer concept are presented

Table 4. Pre-service Primary Teachers' Mental Models' Categories Conceptual Understanding Level Tests

\begin{tabular}{lcccccc}
\hline Model Mental Categories & \multicolumn{5}{c}{ Question } & \\
& & $\begin{array}{c}1 \\
\text { (Conduction) }\end{array}$ & $\begin{array}{c}2 \\
\text { (Convection) }\end{array}$ & $\begin{array}{c}3 \\
\text { (Radiation) }\end{array}$ \\
\hline Scientific & 0 & $0 \%$ & 0 & $0 \%$ & 0 & $0 \%$ \\
Synthetic & 9 & $22.5 \%$ & 13 & $32.5 \%$ & 26 & $65 \%$ \\
Initial & 31 & $77.5 \%$ & 27 & $67.5 \%$ & 14 & $35 \%$ \\
Total & 40 & $100 \%$ & 40 & $100 \%$ & 40 & $100 \%$ \\
\hline
\end{tabular}

From Table 4 it can be seen, there are no pre-service primary teachers on the conduction concept in a scientific mental model category because the pre-service primary teachers' description and visual responses have not been able to provide a scientific explanation. In the conduction concept, most pre-service primary teachers are in the initial mental models' category, meaning that the description and visual response's response only explains the concept of conduction according to the initial understanding is not scientific. Furthermore, there are no pre-service primary teachers who have a mental scientific model category for the concept of convection. Most pre-service primary teachers are in the category of initial mental models. Similarly, there are no pre-service primary teachers in the scientific mental models' category for the concept of radiation. Most pre-service primary teachers are in the synthetic mental model category. 


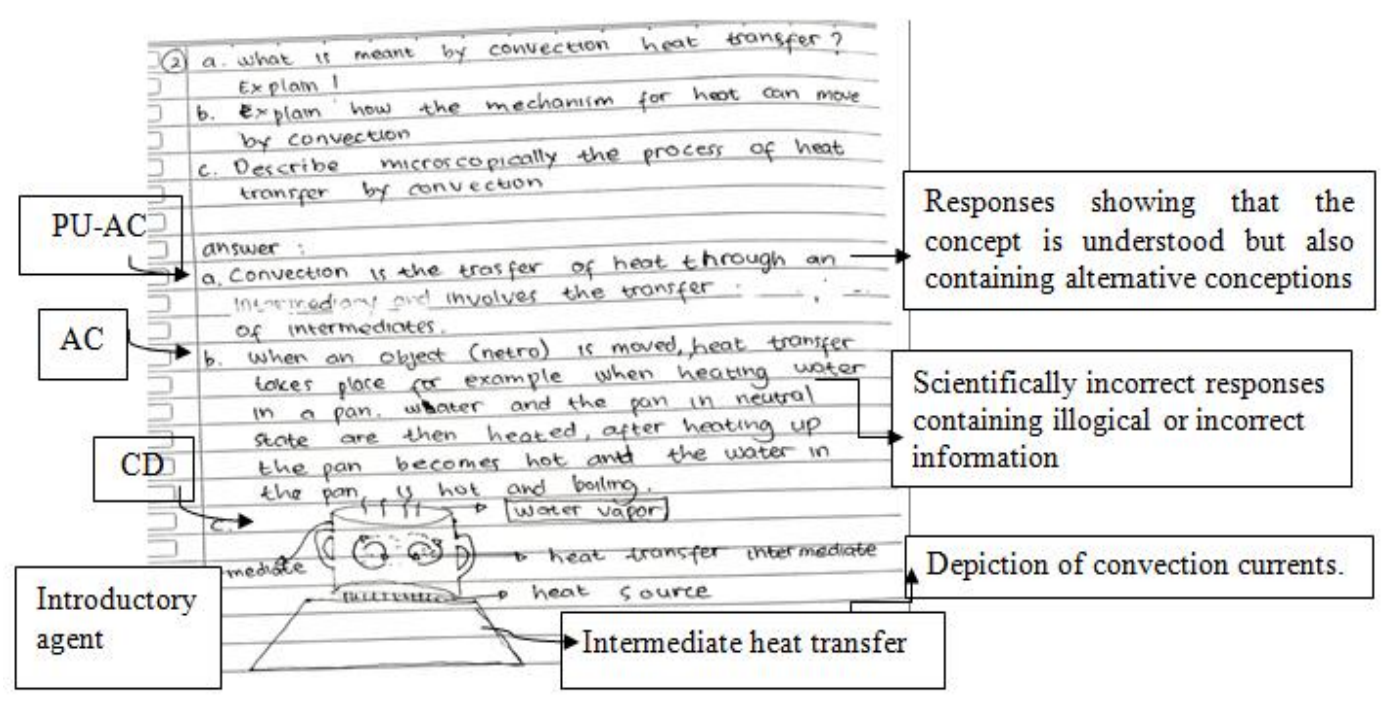

Figure. 4. Pre-service Primary Teachers' Response in the Synthetic Category

Figure 4 shows pre-service primary teachers' response to answer A, including the PU-AC understanding level. The response given shows that the heat transfer by convection concept has been understood but also still contains other conceptions. For answer B includes the level of understanding $\mathrm{AC}$ and for answer $\mathrm{C}$ includes understanding $\mathrm{CD}$ - level because images that reflect heat transfer by convection component are included in the scientific depiction.

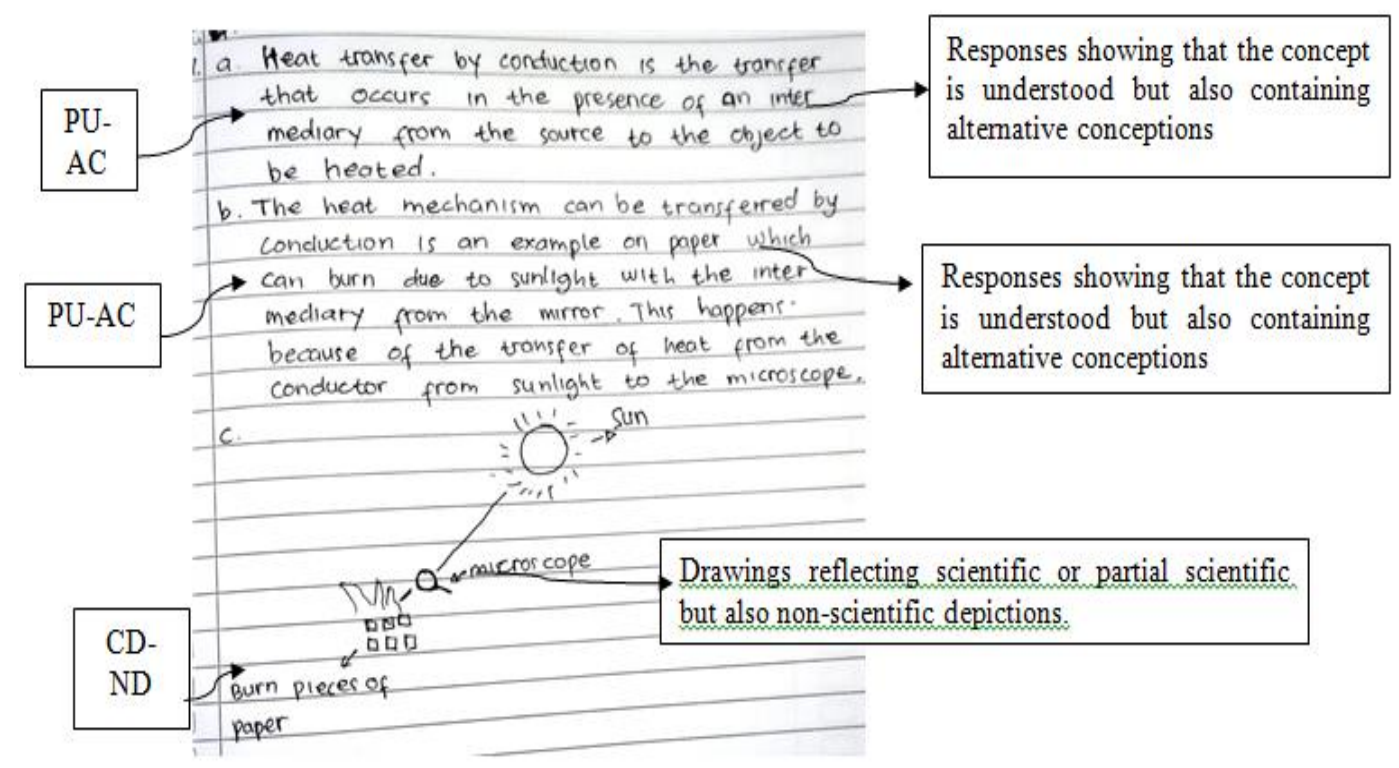

Figure. 5. Pre-service primary teachers' response in the Initial Category

Figure 5 shows pre-service primary teachers to answer A including PU-AC understanding level, because the responses given show that heat transfer by conduction concept is already understood but also contains another conception, answer B includes the PU-AC understanding level, and for answer $\mathrm{C}$ includes the CD-ND understanding level.

\section{Comparison of Primary Teachers and Pre-service Primary Teachers' Mental Models}

Pre-service primary teachers' mental models' categories on heat transfer concept are presented in Table 4. 


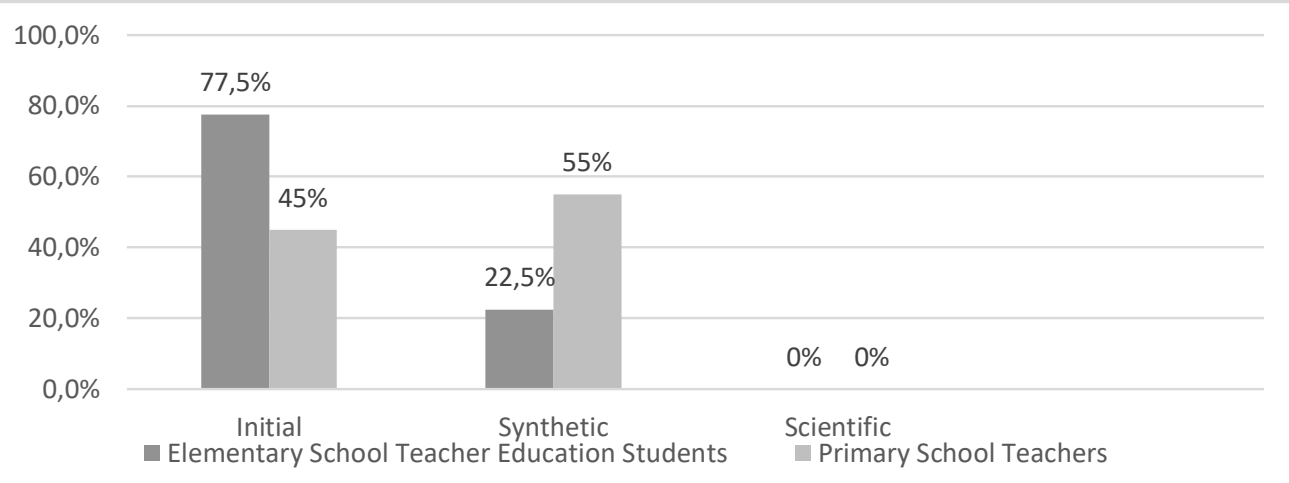

Figure. 6. Comparison of Primary Teachers and Pre-service Primary Teachers' Mental Models on Conduction Concept

From Figure 6, the comparison of the percentage of mental models in the scientific category heat transfer by conduction concept that primary teachers and pre-service primary teachers both get results as much as $0 \%$. In the synthetic category, the percentage of teachers is $32 \%$ higher than preservice primary teachers. Furthermore, pre-service primary teachers in the initial mental models category have a percentage of $33 \%$ higher than primary teachers.

Primary teachers are in the synthetic mental model category, while pre-service primary teachers are in the initial category in answering test questions on heat transfer by conduction concept. Furthermore, a comparison of primary teachers and pre-service primary teachers' mental models on the concept of convection is presented in Figure 7.

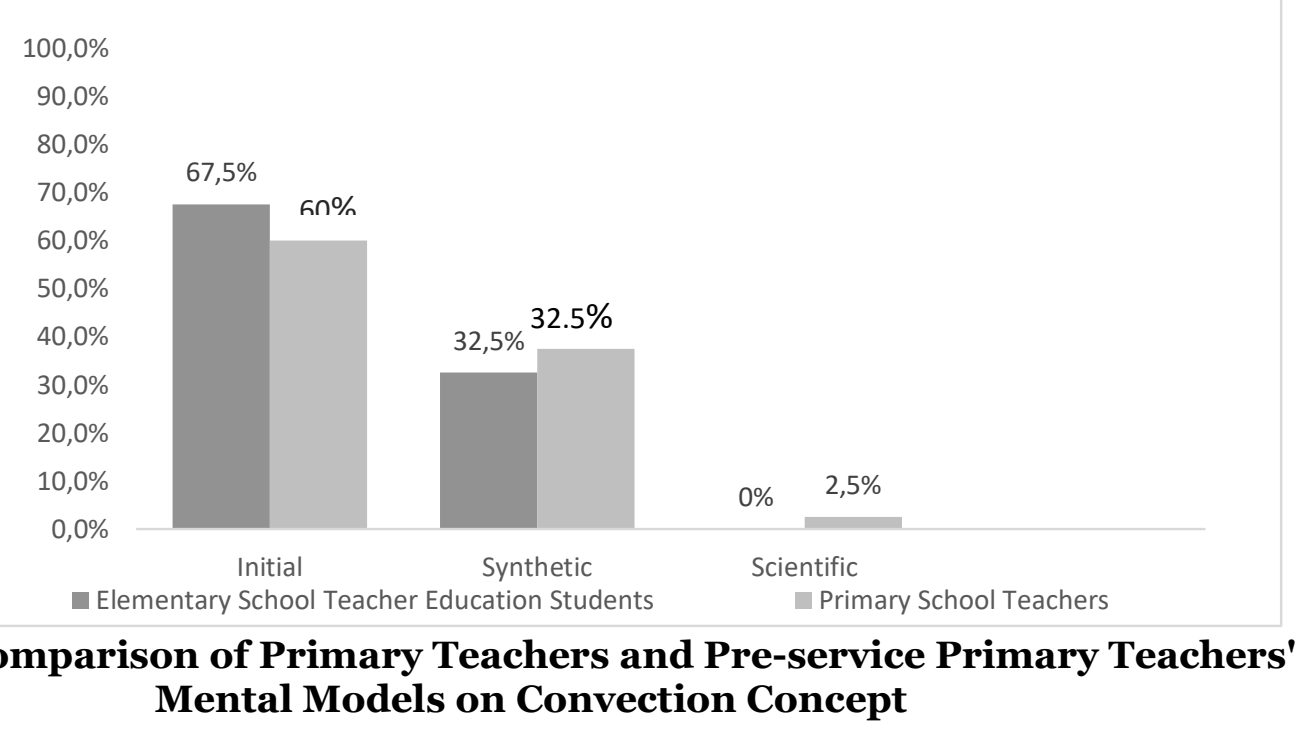

Based on Figure 7, primary teachers have 2.5\% higher percentage than in the mental scientific model category on heat transfer material by convection. Primary teachers have a percentage of $5 \%$ higher than in the synthetic category. Then, the comparison is $7.5 \%$, where pre-service primary teachers are more in this category than primary teachers in the initial mental model category. In general, primary teachers and pre-service primary teachers are in the initial category in answering test questions. However, in the concept of heat transfer by convection.

For comparison of mental models on the concept of heat transfer by radiation, the data is presented in Figure 8. 


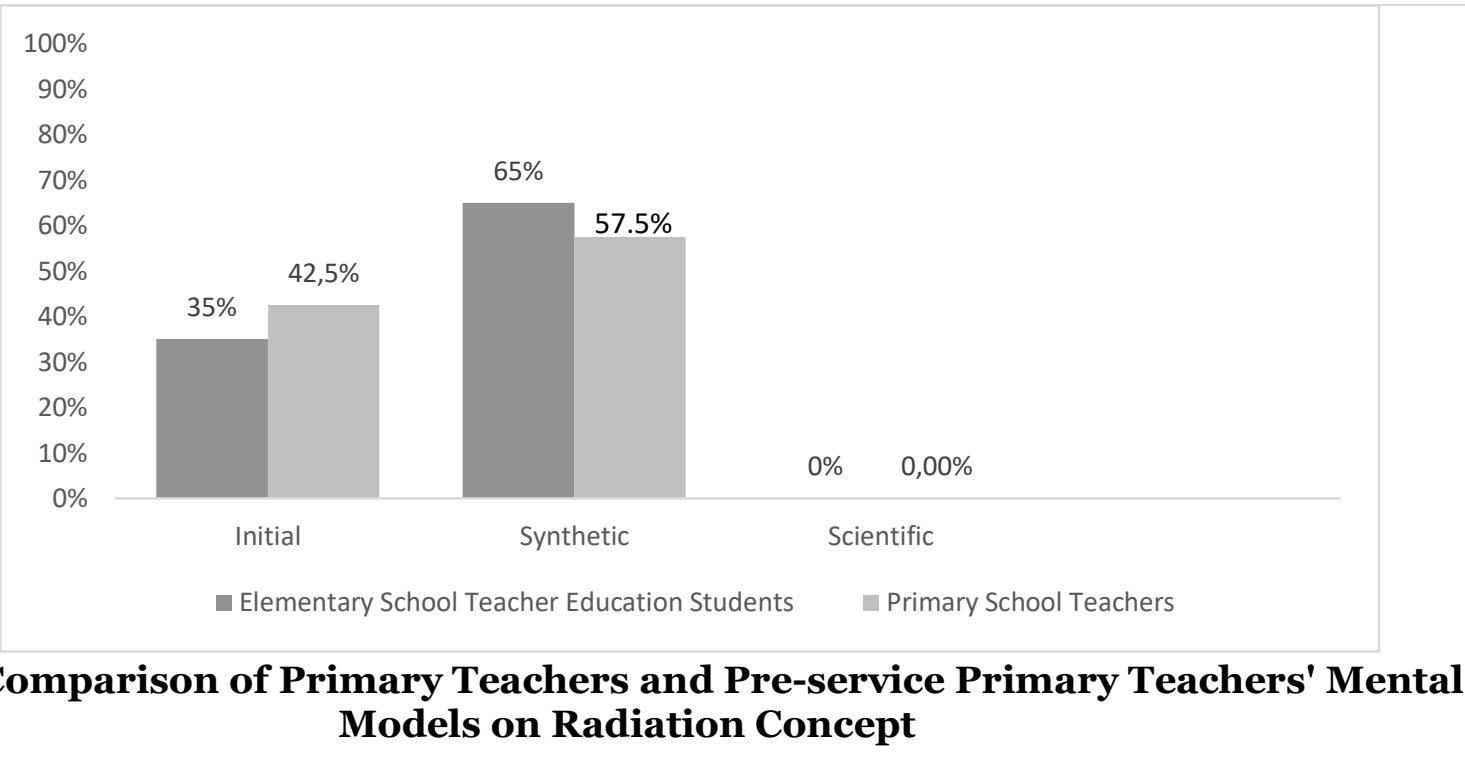

From Figure 8 the comparison of the percentage of mental models in the scientific category shows that primary teachers and pre-service primary teachers both get results as much as $0 \%$ on the heat transfer material by radiation. Comparison in the synthetic category is as much as $7.5 \%$, where the percentage of and pre-service primary teachers is higher compared to primary teachers. Furthermore, in the category of initial mental models, it is $7.5 \%$, with the percentage of primary teachers higher than pre-service primary teachers. In general, primary teachers and pre-service primary teachers are in the synthetic category in answering heat transfer radiation test questions.

Based on the research results, primary teachers' level of understanding and pre-service primary teachers' level of understanding is divided into two, namely the level of understanding for descriptive responses and the level of understanding for visual responses. At the level of conceptual understanding in descriptions and the level of visual understanding, primary teachers are at the level of conceptual understanding level 3 (PU or PCD), level 2 (PU-AC or CD-ND), level 1 (AC or ID), and level o (NU or ND) for descriptive answers and only $1.25 \%$ of primary teachers are at the level of understanding level 4 (SU) and for visual responses, there are $2.5 \%$ of primary teachers who are at level 4 understanding level (CD) for all related heat transfer concepts conduction, convection and radiation. For the level of conceptual understanding of pre-service primary teachers. At the level of conceptual understanding in descriptions and the level of visual understanding, pre-service primary teachers are at the level of conceptual under-standing level 3 (PU or PCD), level 2 (PU-AC or CDND), level 1 ( AC or ID) and level o (NU or ND) for descriptive answers as much as $3.75 \%$ of students are at level $4(\mathrm{SU})$. At the level of visual conceptual understanding, there are as many as $5 \%$ of students' answers to pre-service primary teachers who provide scientific answers or CDs.

Furthermore, there is only 1 teacher out of 40 teachers who can achieve the scientific mental model for the mental model category, while no student reaches the scientific mental model. Most of the primary teachers and pre-service primary teachers are in the initial mental model and there is also a synthetic mental model. In Figure 6, the concept of conduction heat transfer, the mental model of elementary school teachers is better than the mental model of elementary school teacher candidates, Figure 7 the concept of convection heat transfer, primary teachers' mental model is better than pre-service primary teachers' mental model, namely the scientific mental model category. The comparison is $2.5 \%$ and Figure 8 on the radiation concept shows that more than $50 \%$ of teachers and students are on a synthetic mental model. The low mental model of teachers and prospective elementary school teacher students can be influenced by inappropriate learning methods. Preservice primary teachers will find it difficult to understand the concept as a whole. This is in line with 
Supriadi et al. (2018), which states that the lack of student mental models is because in the learning process students are rarely given learning that can improve students' scientific abilities.

These results indicate that very few primary teachers and pre-service primary teachers were able to achieve the category of scientific mental models on each concept or as a whole, the mental model profiles of primary teachers and pre-service primary teachers were still in the category of initial mental models or initial mental models which means, in answering questions of primary teachers and pre-service primary teachers were giving responses that are irrelevant to scientific concepts and have not been able to respond to the form of images that reflect the scientific components of depiction, so the answers cannot be accepted. These results also indicate that the learning process in the classroom has not facilitated the achievement of the scientific mental model category (scientific) in students. Primary teachers and pre-service primary teachers only provide verbal explanations or depictions based on knowledge from real-world or daily life experiences.

This study also indicates that the implementation of the traditional lecture approach does not train mental models of scientific categories. The steps to the conventional lecture approach expressing concepts by giving words, defining concepts, identifying and differentiating concepts to understand the definition, finding the application of related and unrelated concepts to the concept being discussed. The implementation of traditional teaching approaches cannot become effective in concept learning (Maddox, 2015). Students identify and memorize the conceptual understanding phase and understand the relationship of the concepts being studied.

In learning that applies the lecture approach is lecturer-centred learning that prioritizes memorization. Conversely, student-centred learning conditions create student conditions where learning conditions create scientific knowledge discovery that involves interactions between teachers and students. Student-centred learning activities produce meaningful constructs (Reznitskaya, 2012).

Meanwhile, based on the previous explanation, mental models can be formed or influenced by various factors, which are grouped into six, namely: teacher explanations, textbooks, language and words, daily life experiences, social environment, and causal and intuition relationships (Chiu \& Lin, 2005). The level of mental models of each teacher and student is different and the way they explain it is also different. This can be seen in their answers which are presented in Table 3 and Table 4. Each individual has their way of building mental models based on experiences, concepts, analytical skills and accuracy in choosing the right concept. This is in line with Vosniadou, Skopeliti, and Ikospentaki (2004), which states that to understand how a system works, people need to build mental models in mind. It is building a network of related concepts and understanding the functional relationships of different aspects and levels of a system based on everyday knowledge and experiences.

\section{CONCLUSION}

The conclusion that can be drawn is that only a few of the primary teachers and pre-service primary teachers have a scientific mental model. The comparison of mental models of primary teachers is low compared to the mental model of pre-service primary teachers. Generally, primary teachers and pre-service primary teachers have a more initial mental model.

\section{ACKNOWLEDGEMENT}

We would like to thank to the Ministry of Research, Technology and Directorate General of Higher Education and Universitas Riau for financial support PTUPT 2019.

\section{REFERENCES}

Amalia, F. R., Ibnu, S., Widarti, H. R., \& Wuni, H. (2018). Students' mental models of acid and base concepts taught using the cognitive apprenticeship learning model. Jurnal Pendidikan IPA Indonesia. https://doi.org/10.15294/jpii.v7i2.14264

Basori, H., Suhandi, A., Samsudin, A., Kaniawati, I., \& Rusdiana, D. (2020). Teaching electrical 
resistance of a conductor concept using the cd-ccoi model supported by dynamic model and dynamic analogy in improving the mental model. Journal of Engineering Science and Technology, (Special Issue on AASEC2019), 39-47.

Badraeni, N., Pamungkas, R. A., Hidayat, W., Rohaeti, E. E., Wijaya, T. T., Sudirman, J. J., \& Barat, J. (2020). Analisis kesulitan siswa berdasarkan kemampuan pemahaman matematik dalam mengerjakan soal pada materi bangun ruang sisi datar. Jurnal Cendekia : Jurnal Pendidikan Matematika, 04(01), 247-253.

Cunhua, L., Ying, Z., Qunzhuang, O., \& Wijaya, T. T. (2019). Mathematics course design based on six questions cognitive theory using hawgent dynamic mathematic. Journal On Education, 02(01), 36-44.

Çepni, S., Ayas, A., Johnson, D., \& Turgut, F. (1997). Fizik Öğretimi: YÖK/Dünya Bankası Milli Eğitimi Geliştirme Projesi, Hizmet Öncesi Eğitimi. Ankara: Bilkent.

Chiou, G.-L. (2013). Reappraising the relationships between physics students' mental models and predictions: An example of heat convection. Physical Review Special Topics - Physics Education Research, 9(1), 010119. https://doi.org/10.1103/PhysRevSTPER.9.010119

Chiu, M. H., \& Lin, J. W. (2005). Promoting fourth graders' conceptual change of their understanding of electric current via multiple analogies. Journal of Research in Science Teaching. https://doi.org/10.1002/tea.20062

Coll, R. K., \& Treagust, D. F. (2003). Investigation of secondary school, undergraduate, and graduate learners' mental models of ionic bonding. Journal of Research in Science Teaching, 40(5), 464-486. https://doi.org/10.1002/tea.10085

Collins, A., \& Gentner, D. (1987). How people construct mental models. In D. Holland \& N. Quinn (Eds.), Cultural models in language and thought (pp. 243-265). Cambridge: Cambridge University Press.

D. Besnard, D. G. (2018). When mental models go wrong: co-occurrences in dynamic, critical systems. International Journal of Human-Computer Studies 60, 117-128.

Didiş, N., Eryılmaz, A., \& Erkoç, Ş. (2014). Investigating students' mental models about the quantization of light, energy, and angular momentum. Physical Review Special Topics $\begin{array}{llll}\text { Physics } & \text { Education } & \text { Research, } & \text { 10(2), }\end{array}$ https://doi.org/10.1103/PhysRevSTPER.10.020127

Gentner, Dedre, \& Stevens, A. L. (2014). Mental models. (D Gentner \& A. . Stevenson, Eds.). Psychology Press.

Goldin, G. A. (2002). Representation in mathematical learning and problem solving. In L. D. English, M. B. Bussi, G. A. Jones, R. A. Lesh, \& D. Tirosh (Eds.), Handbook of international research in mathematics education (pp. 218-218). London.

Halim, N. D. A., Ali, M. B., Yahaya, N., \& Said, M. N. H. M. (2013). Mental model in learning chemical bonding: A preliminary study. Procedia-Social and Behavioral Sciences, 97, 224-228.

Hermita, N. (2017). Pengembangan visual multimedia supported conceptual change text (VMMVSCCTEXT) materi kelistrikan dan kemagnetan untuk pengajaran remedial berorientasi konstruksi-rekonstruksi konsepsi ilmiah mahasiswa calon guru SD. Universitas Pendidikan Indonesia.

Hermita, N., Parlina, T. A., Putra, Z. H., Alpusari, M., Alim, J. A., Sari, I. K., ... Suhandi, A. (2020). Identifying of elementary students' mental Model on gravity concept. International Journal of Advanced Science and Technology, 29(5), 6772-6780.

Hutajulu, M., Wijaya, T. T., \& Hidayat, W. (2019). the Effect of Mathematical Disposition and Learning Motivation on Problem Solving: an Analysis. Infinity Journal, 8(2), 229. https://doi.org/10.2246o/infinity.v8i2.p229-238

Jia, Q. (2010). A brief study on the implication of constructivism teaching theory on classroom teaching reform in basic education. International Education Studies, 3(2), 197-199.

Johnson-Laird, P. N. (2013). Mental models and cognitive change. Journal of Cognitive Psychology, 25(2), 131-138. https://doi.org/10.1080/20445911.2012.759935

Jones, N. A., Ross, H., Lynam, T., Perez, P., \& Leitch, A. (2011). Mental models: an interdisciplinary synthesis of theory and methods. Ecology and Society, 16(1).

Khasanah, N., Wartono, W., \& Yuliati, L. (2016). Analysis of mental Model of students using isomorphic problems in dynamics of rotational motion topic. Jurnal Pendidikan IPA Indonesia, 5(2), 186-191. https://doi.org/https://doi.org/10.15294/jpii.v5i2.5921 
Kulsum, S. I., Hidayat, W., Wijaya, T. T., \& Kumala, J. (2019). Analysis on high school students' mathematical creative thinking skills on the topic of sets. Jurnal Cendekia: Jurnal Pendidikan $\quad$ Matematika, 03(02), 431-436. https://doi.org/https://doi.org/10.31004/cendekia.v3i2

Kurnaz, M. A., \& Eksi, C. (2015). An Analysis of High School Students' Mental Models of Solid Friction in Physics. Educational Sciences: Theory \& Practice, 15(3). https://doi.org/10.12738/estp.2015.3.2526

Laliyo, L. A. R. (2011). Model mental siswa dalam memahami perubahan wujud zat. Jurnal Penelitian Dan Pendidikan, 8(1), 1-12.

Maddox, G. A. (2015). Human category learning. Annual Review of Psychology 56, 149-178.

Notoatmodjo, S. (2010). Metodologi penelitian kesehatan. Jakarta: Rineka Cipta.

Parlina, T. A., Hermita, N., Alpusari, M., \& Noviana, E. (2019). Identifying Pupils' Mental Model of the Day and Night Concept. Journal Of Teaching and Learning in Elementary Education, 2(2), 118-125.

Qin, L., Zhou, Y., \& Tanu, W. T. (2019). The Analysis of Mathematics Adversity Quotient of Left Behind Junior High School Students in Rural Areas. Open Journal of Social Sciences, 331342. https://doi.org/10.4236/jss.2019.710028

Reznitskaya, A. (2012). Dialogic Teaching: Rethinking Language Use During Literature Discussions. The Reading Teacher, 65(7), 446-456. https://doi.org/10.1002/TRTR.01066

Senge, P. (1990). The fifth discipline: The art and practice of the learning organization. New York: Currency Doubleday. Currency.

Suhandi, A., Rusdiana, D., Samsudin, A., \& Wibowo, F. C. (2019). Identifying pre-service physics teacher mental model on electric conceptions. In Journal of Physics: Conference Series (Vol. 1204, p. 12058). IOP Publishing.

Supriadi, S., Ibnu, S., \& Yahmin, Y. (2018). Analisis model mental mahasiswa pendidikan kimia dalam memahami berbagai jenis reaksi kimia. Jurnal Pijar MIPA, 13(1), 1-5. https://doi.org/10.29303/jpm.v13i1.433

Vosniadou, S., Skopeliti, I., \& Ikospentaki, K. (2004). Modes of knowing and ways of reasoning in elementary astronomy. Cognitive Development, 19(2), 203-222. https://doi.org/10.1016/j.cogdev.2003.12.002.

Westbrook, L. (2006). Mental Models: A Theoretical Overview and Preliminary Study. Journal of Information Science; 32, 563-579.

Wijaya, T.T., Dewi, N. S. S., Fauziah, I. R., \& Afrilianto, M. (2018). Analisis Kemampuan Pemahaman Matematis Siswa Kelas IX Pada Materi Bangun Ruang. UNION: Jurnal Ilmiah Pendidikan Matematika, 6(1), 19-28. https://doi.org/10.30738/.v6i1.2076

Wijaya, T.T., Jianlan, T., \& Aditya, P. (2020). Developing an Interactive Mathematical Learning Media Based on the TPACK Framework Using the Hawgent Dynamic Mathematics Software. Emerging Technologies in Computing, 318-328. https://doi.org/10.1007/978-3-03060036-5

Wijaya, T.T., Ying, Z., \& Purnama, A. (2020a). The empirical research of hawgent dynamic mathematics technology integrated into teaching. Journal Cendekia: Jurnal Pendidikan Matematika, 04(01), 144-150.

Wijaya, T.T., Ying, Z., \& Purnama, A. (2020b). Using Hawgent Dynamic Mathematics Software in Teaching Trigonometry. International Journal of Emerging Technologies in Learning, 15(10), 215-222. https://doi.org/10.3991/ijet.v15i10.13099

Wijaya, T.T., Ying, Z., \& Suan, L. (2020). Gender and Self-regulated Learning During COVID-19 Pandemic in Indonesia. Jurnal Basicedu, 4(3), 725-732. https://doi.org/10.31004/basicedu.v4i3.422

Wijaya, T.T., Ying, Z., \& Ya, G. (2020). Investigation on The Attitude of Mathematics Education Students Towards Learning Mathematics in Guilin Attitude students. 8(1), 1-6.

Wijaya, Tommy Tanu, Ying, Z., Chotimah, S., \& Bernard, M. (2020). Hawgent dynamic mathematic software as mathematics learning media for teaching quadratic functions. https://doi.org/10.1088/1742-6596/1592/1/012079 